\title{
Differential Vulnerability to Excitatory Amino Acid-Induced Toxicity and Selective Neuronal Loss in Neurodegenerative Diseases
}

\author{
John H. Weiss and Dennis W. Choi
}

\begin{abstract}
Neurodegenerative diseases are characterized by selective degeneration of certain biochemically distinct subpopulations of central neurons. Studies of the intrinsic vulnerability of such neurons to injury by excitatory amino acids in vitro, as well as study of neurologic syndromes produced in animals or humans by ingestion of environmental excitatory amino acid neurotoxins may suggest a link between excitotoxicity, and the pathogenesis of certain neurodegenerative diseases.

RÉSUMÉ: Vulnérabilité différentielle à la toxicité induite par des acides aminés excitateurs et perte neuronale sélective dans les amladies neurodégénératives. Les maladies neurodégénératives sont caractérisées par une dégénérescence sélective de certaines sous-populations de neurones centraux biochimiquement distinctes. Des études de la vulnérabvilité intrinsèque de ces neurones à une atteinte par des acides aminés excitateurs in vitro, ainsi que l'étude des syndromes neurologiques causés chez l'animal ou chez l'humain par l'ingestion de neurotoxines environnementales qui sont des acides aminés excitateurs, peuvent suggérer qu'il existe un lien entre l'excitotoxicité et la pathogenèse de certaines maladies neurodégénératives.
\end{abstract}

Can. J. Neurol. Sci. 1991; 18:394-397

There is now substantial evidence that excitatory amino acidinduced neurotoxicity (excitotoxicity) can contribute to the neuronal injury triggered by acute insults to the central nervous system. 1,2. In part based on this precedent, there has been growing recent interest in the possibility that excitotoxicity might also participate in the pathogenesis of the selective neuronal loss accompanying certain neurodegenerative diseases, including Huntington's disease (HD), Alzheimer's disease (AD), and amyotrophic lateral sclerosis (ALS).

While glutamate activates both $\mathrm{N}$-methyl-D-aspartate (NMDA), and non-NMDA (kainate, and alpha-amino-3hydroxy-5-methyl-4-isoxazolepropionic acid [AMPA]/ quisqualate) receptors, ${ }^{3}$ the excitotoxicity associated with several acute insults to the central nervous system may be predominantly mediated by NMDA receptor activation. This predominance may reflect a key role of NMDA receptors in mediating the degeneration of cortical or hippocampal neurons induced by brief exposure to high concentrations of glutamate. 4,5 Yet, with prolonged exposures, non-NMDA agonists are also potent neurotoxins and can produce widespread neuronal destruction. 6

The injection of kainate into rat striatum destroys intrinsic striatal neurons with sparing of afferent axons, a lesion sharing some features with the pathology of HD.7.8 In 1985, Ferrante et al. ${ }^{9}$ discovered that the degeneration of striatal neurons in HD was strikingly selective, in that the small neuronal subpopula- tion containing high concentrations of the enzyme, NADPHdiaphorase (NADPH-d(+) neurons), remained largely intact amid extensive loss of other intrinsic striatal neurons. This new pathological feature challenged the excitotoxin injection model, and Beal et al. ${ }^{10}$ found that kainate failed to spare NADPH-d(+) neurons. In fact, of several excitotoxins studied by those investigators, only the NMDA agonist quinolinate successfully mimicked the pattern of striatal neuronal loss sparing NADPH-d(+) neurons, favoring the idea that quinolinate might be specifically involved in HD pathogenesis. ${ }^{10,11}$ However, other investigators did not see NADPH-d(+) neuronal sparing with quinolinate injection. ${ }^{12,13}$

We set out independently to characterize the excitotoxic vulnerability of cultured cortical NADPH-d(+) neurons, a population sharing the property of somatostatin co-localization with striatal counterparts. We reasoned that NADPH-d(+) neurons might be intrinsically resistant to excitotoxicity, although such intrinsic resistance would only be one of several possible explanations of resistance to excitotoxicity in vivo. The damage induced by administration of an excitotoxin in vivo might additionally reflect cellular access, uptake, and the extent of secondary damage induced by release of endogenous excitatory amino acids. In the open architecture of cell culture, the first two factors are attenuated, and intrinsic neuronal vulnerability can be quantitatively assessed. 
Consistent with the results of Beal et al, we found that cultured cortical NADPH-d(+) neurons, ${ }^{14}$ and their striatal counterparts, ${ }^{15}$ were selectively resistant to quinolinate neurotoxicity; however in contrast, we found that this selective resistance generalized to other NMDA agonists. Since this resistance was not absolute, it seemed plausible that divergent results in vivo might reflect small differences in technique and resultant differences in the concentration profiles of excitotoxin attained. Indeed subsequently Beal et al. 16 reexamined striatal lesions induced by injection of submaximal amounts of NMDA, and found NADPH$\mathrm{d}(+)$ neuronal sparing that they had not seen previously.

An attractive site for explaining the resistance of NADPH$\mathrm{d}(+)$ neurons to damage by NMDA agonists might be at the receptor level (e.g., a paucity of NMDA receptors, or reduced receptor affinity for NMDA or glycine). NADPH-d(+) cells are not simply hard to kill, as they are preferentially destroyed by kainate or quisqualate. ${ }^{17}$ Additional support for involvement of NMDA receptor-mediated injury in HD was provided by the observation that another neuronal population spared in HD, neurons containing acetylcholinesterase, is also resistant to NMDA receptor-mediated injury; 15 and the finding that NMDA receptor number may be greatly reduced in HD striatum. 18

The possibility that excitotoxicity may participate in the pathogenesis of ALS has been raised by suggestions of aberrant glutamate metabolism in ALS patients..$^{19-21}$ Precedent is provided by three environmentally-induced motor system diseases, lathyrism, the ALS-Parkinsonism-dementia complex of Guam (ALS-PD), and domoate poisoning. Lathyrism is characterized by spastic paraparesis; it is caused by excessive consumption of an unusual excitotoxin, beta- $\mathrm{N}$-oxalylamino-L-alanine (BOAA), present at high concentrations in the chickling pea. ${ }^{22-24}$ Toxicity, electrophysiology and binding studies all indicate that BOAA is a potent and selective agonist at non-NMDA receptors. 25,26

Guam ALS-PD is a restricted form of ALS that occurs with high prevalence among the Chamorro people in Guam,27 often in association with some clinical and pathological features of Parkinsonism or Alzheimer-type dementia.28,29 While the cause of Guam ALS-PD is unknown, it appears from epidemiological considerations to be environmentally-induced. ${ }^{30}$ One theory links it to consumption of the cycad plant excitotoxin, beta-Nmethylamino-L-alanine (BMAA); in macaques, chronic BMAA ingestion can damage upper and lower motor neurons. ${ }^{31}$ Despite lacking the side-chain electronegative group characteristic of other excitatory amino acids, BMAA can induce seizures in rodents ${ }^{32}$ and excitotoxic neuronal degeneration in CNS explant tissue; 25,31 most likely, extracellular bicarbonate $/ \mathrm{CO}_{2}$ interacts with BMAA to produce a combined structure capable of activating glutamate receptors ${ }^{33}$ - possibly after carbamate formation. ${ }^{34}$ Although the neurotoxicity induced by high concentrations of BMAA may be largely mediated by NMDA receptors, $25,31,35$ low concentrations of BMAA selectively destroys NADPH-d(+) neurons and thus may preferentially activate non-NMDA receptors. ${ }^{35} \mathrm{~A}$ recent binding study has also suggested that BMAA interacts with non-NMDA receptors. ${ }^{36}$

Domoate is a potent kainate agonist. ${ }^{37}$ Domoate poisoning, due to ingestion of contaminated mussels, has been recently recognized as a clinical entity ${ }^{38}$ characterized by seizures and other neurological disturbances; of note, electrophysiological studies have suggested denervation of muscle consistent with damage to motor neurons or axons. ${ }^{39}$ Pathological correlates of this denervation will be an important topic for future investigation.

The apparent ability of several non-NMDA agonists BOAA, BMAA (at least experimentally), and domoate - to damage the primate motor system supports the hypothesis that nonNMDA receptor overstimulation might contribute to the pathogenesis of sporadic ALS. Furthermore, electrophysiologic studies have suggested that motor neurons are highly sensitive to kainate, perhaps more so than to NMDA; $; 0,41$ and intrathecal injection of kainate has been recently found to preferentially damage neurons in ventral hom. ${ }^{42}$

Excitotoxicity mediated through NMDA receptors has also been proposed to participate in the pathogenesis of $\mathrm{AD},{ }^{43}$ based on several arguments including distribution of pathology. Whether or not NMDA receptors are preferentially lost has been controversial. 43,44 We have raised the alternative speculation that any excitotoxic involvement in AD may be specifically mediated via non-NMDA receptors. ${ }^{45}$ The small subpopulation of cortical neurons containing somatostatin (SS), which as a population overlap substantially with the NADPH-d(+) population, may be selectively damaged in early AD.46-48 Another cortical neuronal subpopulation possibly sustaining early damage in $\mathrm{AD}$ may be neurons containing high concentrations of the calcium binding protein, parvalbumin (PV). ${ }^{49}$ Both SS $(+)$ and PV $(+)$ neurons are relatively resistant to NMDA receptor-mediated toxicity and unusually sensitive to non-NMDA receptormediated toxicity. ${ }^{50}$ Also, whatever the cause of Guam ALS$\mathrm{PD}$, the concurrence of AD-like features with ALS-like features in that disease raises the possibility that $\mathrm{AD}$ may share some mechanisms with ALS, perhaps including non-NMDA receptormediated toxicity. Glutamate-induced degeneration of cultured hippocampal neurons is associated with increased immunostaining with antibodies directed against $\mathrm{AD}$ neurofibrillary tangles. 51

Many different specific derangements in the glutamate system could eventually lead to the toxic overactivation of NMDA or non-NMDA receptors in a neurodegenerative disease. These derangements need not be primary disease manifestations, for example a direct effect of the HD gene, but could come about secondarily after a cascade of earlier pathological events. An excitotoxic pattern of neuronal loss would result as long as excitotoxicity contributed importantly to net injury.

Increases in the ambient concentrations of glutamate or other endogenous excitatory amino acid, such as aspartate, homocysteate or quinolinate, could result from increased production or release, or deficient uptake or metabolism. Another endogenous excitotoxin is the amino acid cysteine, that like BMAA may be dependent on bicarbonate for its toxic properties. 52 The postsynaptic neuron could have an increased density of glutamate receptors, abnormal receptors, or a reduced ability to handle the metabolic stress induced by normal levels of excitatory synaptic activity. Calcium metabolism could be particularly important. ${ }^{53}$ Interestingly, neurons in elderly animals appear to have greater calcium fluxes through voltage-gated calcium channels, and longer lasting calcium action potentials, than neurons in young animals. ${ }^{54.55}$ Thus it is possible that the calcium influx induced by non-NMDA receptor activation could increase with aging, a factor which might favor gradual excitotoxic damage. 
The postulate of glutamate receptor-mediated neurotoxicity in the pathogenesis of $\mathrm{HD}$, ALS OR AD suggests a possible avenue for therapeutic intervention. Specific agents might be directed at either presynaptic or postsynaptic sites, for example decreasing glutamate release, blocking glutamate receptors, reducing excitotoxic amplification, or blocking the expression of excitotoxicity downstream from receptor overactivation. .6 Given the lack of good animal models for these diseases, clinical trials with suitable anti-excitotoxic agents may be the only way to determine the extent to which excitotoxicity contributes to pathogenesis. A key task for the future will be the development of anti-excitotoxic agents sufficiently free of side effects to be suitable for long-term administration in humans.

\section{ACKNOWLEDGEMENTS}

Supported by NIH grant NS26907 and a Clinician Investigator Award (\# AG00495-01, to J.H.W.) from the NIA.

\section{REFERENCES}

1. Rothman SM, Olney JW. Glutamate and the pathophysiology of hypoxic-ischemic brain damage. Ann Neurol 1986; 19: 105-111.

2. Choi DW. Glutamate neurotoxicity and diseases of the nervous system. Neuron 1988; 1: 623-634.

3. Watkins, JC, Olverman HJ. Agonists and antagonists for excitatory amino acid receptors. Trends Neurosci 1987; 10: 265-272.

4. Choi DW, Koh J, Peters S. Pharmacology of glutamate neurotoxicity in cortical cell culture: attenuation by NMDA antagonists. J Neurosci 1988; 8: 185-196.

5. Michaels RL, Rothman SM. Glutamate neurotoxicity in vitro: Antagonist pharmacology and intracellular calcium concentrations. J Neurosci 1990; 10: 283-292.

6. Koh J, Goldberg MP, Hartley DM, et al. Non-NMDA receptormediated neurotoxicity in cortical culture. J Neurosci 1990; 10: 693-705.

7. McGeer EG, McGeer PL. Duplication of biochemical changes of Huntington's chorea by intrastriatal injections of glutamic and kainic acids. Nature $1976 ; 263$ : 517-519.

8. Coyle JT, Schwarcz R. Lesion of striatal neurones with kainic acid provides a model for Huntington's chorea. Nature 1976; 263 : 244-246.

9. Ferrante RJ, Kowall NW, Beal MF, et al. Selective sparing of a class of striatal neurons in Huntington's disease. Science 1985; 230: $561-563$.

10. Beal MF, Kowall NW, Ellison DW, et al. Replication of the neurochemical characteristics of Huntington's disease by quinolinic acid. Nature 1986; 321: 168-171.

11. Schwarcz R, Whetsell WO Jr, Mangano RM. Quinolinic acid: an endogenous metabolite that produces axon-sparing lesions in rat brain. Science 1983; 219:316-318.

12. Davies SW, Roberts PJ. No evidence for preservation of somatostatin-containing neurons after intrastriatal injections of quinolinic acid. Nature 1987; 327: 326-329.

13. Boegman RJ, Parent A. Differential sensitivity of neuropeptide Y, somatostatin and NADPH-diaphorase containing neurons in rat cortex and striatum to quinolinic acid. Brain Res 1988; 445: 358362.

14. Koh J, Peters S, Choi DW. Neurons containing NADPH-diaphorase are selectively resistant to quinolinate toxicity. Science 1986; 234: 73-76.

15. Koh J, Choi DW. Cultured striatal neurons containing NADPHdiaphorase or acetylcholinesterase are selectively resistant to injury by NMDA receptor agonists. Brain Res 1988; 446: 374-378.

16. Beal MF, Kowall NW, Swartz KJ, et al. Differential sparing of somatostatin-neuropeptide $Y$ and cholinergic neurons following striatal excitotoxin lesions. Synapse 1989; 3: 38-47.
17. Koh J, Choi DW. Vulnerability of cultured cortical neurons to damage by excitotoxins: differential susceptibility of neurons containing NADPH-diaphorase. J Neurosci 1988; 8: 2153-2163.

18. Young AB, Greenamyre JT, Hollingsworth D, et al. NMDA receptor losses in putamen from patients with Huntington's Disease. Science 1988; 241: 981-983.

19. Plaitakis A, Caroscio JT. Abnormal glutamate metabolism in amyotrophic lateral sclerosis. Ann Neurol 1987; 22: 575-579.

20. Hugon J, Tabaraud F, Rigaud M, et al. Glutamate dehydrogenase and aspartate aminotransferase in leukocytes of patients with motor neuron disease. Neurology 1989; 39: 956-958.

21. Rothstein JD, Tsai G, Kuncl RW, et al. Abnormal excitatory amino acid metabolism in amyotrophic lateral sclerosis. Ann Neurol 1990; 28: 18-25.

22. Watkins JC, Curtis DR, Biscoe TJ. Central effects of beta-N-oxalylalpha, beta-diaminopropionic acid and other lathyrus factors. Nature 1966; $211: 637$.

23. Olney JW, Misra CH, Rhee V. Brain and retinal damage from lathyrus excitotoxin, beta-N-oxalyl-L- alpha, beta-diaminopropionic acid. Nature 1976; 264: 659-661.

24. Spencer PS, Ludolph A, Dwivedi MP, et al. Lathyrism: evidence for role of the neuroexcitatory aminoacid BOAA. Lancet 1986; 2: $1066-1067$

25. Ross SM, Seelig M, Spencer PS. Specific antagonism of excitotoxic action of "uncommon" amino acids assayed in organotypic mouse cortical cultures. Brain Res 1987; 425: 120-127.

26. Bridges RJ, Stevens DR, Kahle JS, et al. Structure-function studies on N-oxalyl-diamino-dicarboxylic acids and excitatory amino acid receptors: evidence that beta-L-ODAP is a selective nonNMDA agonist. J Neurosci 1989; 9: 2073-2079.

27. Arnold A, Edgren DC, Palladino VS. Amyotrophic lateral sclerosis, fifty cases observed on Guam. J Nerv Ment Dis 1953; 114: 135139.

28. Hirano A, Kurland LT, Krooth RS, et al. Parkinsonism-dementia complex, an endemic disease on the island of Guam. I. Clinical Features. Brain 1961; 84: 641-661.

29. Hirano A, Malamud N, Kurland LT. Parkinsonism-dementia complex, an endemic disease on the island of Guam. II. Pathological Features. Brain 1961; 84: 662-680.

30. Plato CC, Garruto RM, Fox KM, et al. Amyotrophic lateral sclerosis and Parkinsonism-dementia on Guam: A 25-year prospective case-control study. Am J Epidemiol 1986; 124: 643-656.

31. Spencer PS, Nunn PB, Hugon J, et al. Guam amyotrophic lateral sclerosis-Parkinsonism-dementia linked to a plant excitant neurotoxin. Science 1987; 237: 517-522.

32. Polsky FI, Nunn PB, Bell EA. Distribution and toxicity of alphaamino-beta-methylaminopropionic acid. Fed Proc 1972; 31: $473-$ 1475.

33. Weiss JH, Choi DW. Beta-N-methylamino-L-alanine neurotoxicity: requirement for bicarbonate as a cofactor. Science 1988; 241 : 973-975.

34. Mroz EA. Possible role of carbamates in neurotoxicity and neurotransmitter inactivation. Science 1989; 243: 1615.

35. Weiss JH, Koh J, Choi DW. Neurotoxicity of beta-N-methylaminoL-alanine (BMAA) and beta-N-oxalylamino-L-alanine (BOAA) on cultured cortical neurons. Brain Res 1989; 497: 64-71.

36. Richter KE, Mena EE. L-beta methylaminoalanine inhibits $\left[{ }^{3} \mathrm{H}\right]$ glutamate binding in the presence of bicarbonate ions. Brain Res $1989 ; 492: 385-388$.

37. Debonnel G, Beauch sne L, De Montigny C. Domoic acid, the alleged "mussel toxin", might produce its neurotoxic effect through kainate receptor activation: an electrophysiologic study in the rat dorsal hippocampus. Can J Physiol Pharmacol 1989; 67: $29-33$.

38. Perl TM, Bedard L, Kosassky T, et al. An outbreak of toxic encephalopathy caused by eating mussels contaminated with domoic acid. New Eng J Med 1990; 322: 1775-1780.

39. Teitelbaum JS, Zatorre RJ, Carpenter $S$, et al. Neurologic sequelae of domoic acid intoxication due to the ingestion of contaminated mussels. New Eng J Med 1990; 322: 1781-1787. 
40. Biscoe TJ, Evans RH, Headley PM, et al. Structure-activity relations of excitatory amino acids on frog and rat spinal neurones. Br J Pharmacol 1976; 58: 373-382.

41. O'Brien RJ, Fischbach GD. Modulation of embryonic chick motoneuron glutamate sensitivity by interneurons and agonists. $J$ Neurosci 1986; 6: 3290-3296.

42. Hugon J, Vallat JN, Spencer PS, et al. Kainic acid induces early and delayed degenerative neuronal changes in rat spinal cord. Neurosci Lett 1989; 104: 258-262.

43. Greenamyre JT, Young AB. Excitatory amino acids and Alzheimer's disease. Neurobiol Aging 1989; 10:593-602.

44. Cotman CW, Geddes JW, Bridges RJ, Monaghan DT. N-methyl-Daspartate receptors in Alzheimer's disease. Neurobiol Aging 1989; 10: 603-605.

45. Choi DW. Non-NMDA receptor-mediated neuronal injury in Alzheimer's disease? Neurobiol Aging 1989; 10: 605-606.

46. Davies P, Katzman R, Terry RD. Reduced somatostatin-like immunoreactivity in cerebral cortex from cases of Alzheimer disease and Alzheimer senile dementa. Nature 1980; 288: 279 280.

47. Rossor MN, Emson PC, Mountjoy CQ, et al. Reduced amounts of immunoreactive somatostatin in the temporal cortex in senile dementia of Alzheimer type. Neurosci Lett 1980; 20: 373-377.

48. Chan-Palay V. Somatostatin immumoreactive neurons in the human hippocampus and cortex shown by immunogold/silver intensification on vibratome sections: coexistence with neuropeptide $Y$ neurons, and effects in Alzheimer-type dementia. J Comp Neurol 1987; 260: 201-223.
49. Arai H, Emson PC, Mountjoy CQ, et al. Loss of parvalbuminimmunoreactive neurons from cortex in Alzheimer-type dementia. Brain Res 1987; 418: 164-169.

50. Weiss JH, Koh J, Baimbridge KG, et al. Cortical neurons containing somatostatin or parvalbumin-like immunoreactivity are atypically vulnerable to excitotoxic injury in vitro. Neurology 1990; 40: 1288-1292.

51. Mattson MP. Antigenic changes similar to those seen in neurofibrillary tangles are elicited by glutamate and $\mathrm{Ca}^{2+}$ influx in cultured hippocampal neurons. Neuron 1990; 2: 105-117.

52. Olney JW, Zorumski C, Price MT, Labruyere J. L-cysteine, a bicarbonate-sensitive endogenous excitotoxin. Science 1990; 248: 596-599.

53. Choi DW. Calcium-mediated neurotoxicity: relationship to specific channel types and role in ischemic damage. Trends Neurosci 1988; 11: 465-469.

54. Campbell LW, Hao SY, Landfield PW. Aging-related increases in L-like calcium currents in rat hippocampal slices. Soc Neurosci Abstr 1989; 15: 260.

55. Kerr DS, Campbell LW, Hao SY, Landfield PW. Corticosteroid modulation of hippocampal potentials: increased effect with aging. Science 1989; 245: 1505-1509.

56. Choi DW. Methods for antagonizing glutamate neurotoxicity. Cerebrovasc Brain Metab Rev 1990; 2: 105-147. 